\title{
OSTEOPOROSIS IN BRAZILIAN PATIENTS AWAITING KNEE ARTHROPLASTY
}

\section{OSTEOPOROSE EM PACIENTES AGUARDANDO ARTROPLASTIA DE JOELLHO NA POPULAÇÃO BRASILEIRA}

\author{
David Sadigursky ${ }^{1,2}$, Luiz Alberto Barretto Junior ${ }^{2}$, Diogo Maciel Vieira Lobão ${ }^{2}$, \\ Rogério Jamil Fernandes Carneiro $^{1}$, Paulo Oliveira Colavolpe ${ }^{1}$
}

1. Clínica Ortopédica Traumatológica (COT), Salvador, BA, Brazil.

2. Faculdade de Tecnologia e Ciências (FTC), Salvador, BA, Brazil.

\section{ABSTRACT}

Objective: The primary objective of this study was to determine the prevalence of osteoporosis and osteopenia prior to total knee arthroplasty (TKA) in female patients. As a secondary objective, we evaluated the incidence of hip fractures, types of drugs to treat osteoporosis and serum vitamin D levels. Method: This is a transversal, descriptive and observational study which evaluated 60 women above age 55 prior to total knee replacement. Results: Mean patient age was 71.4 years. Osteoporosis was present in $16.7 \%$ of the sample and osteopenia in $15 \%$. In the patients with osteoporosis, femur fracture (20\%) was most frequent. Most of the group with osteopenia did not take any medication to treat this condition (55.6\%), while most patients with osteoporosis took alendronate (30\%) and $30 \%$ did not take any medication. Conclusion: The female population awaiting total knee replacement should be considered at risk for osteoporosis, confirming recent findings in the literature. Level of Evidence III, Control Case Study.

Keywords: Osteoporosis. Climacteric. Arthroplasty.

\section{RESUMO}

Objetivo: O objetivo primário do estudo foi determinar a prevalência de osteoporose e osteopenia no pré-operatório de artroplastia total de joelho (ATJ) em pacientes do sexo feminino. Como objetivos secundários, avaliamos a incidência de fraturas de fêmur, o uso de medicações para o tratamento da osteoporose e os níveis da 25-OH vitamina D. Método: É um estudo transversal, descritivo e observacional. A amostra foi composta por 60 mulheres com idade acima de 55 anos, no climatério, em pré-operatório de ATJ. Resultados: A média de idade foi de 71,4 anos. A osteoporose estava presente em $16,7 \%$ e a osteopenia em $15 \%$ da amostra estudada. Entre os pacientes com osteoporose, a fratura de fêmur foi a mais frequente (20\%). A maioria do grupo com osteopenia não usava medicação para tratar essa afecção (55,6\%), enquanto a maior parte dos pacientes com osteoporose usava alendronato (30\%) e 30\% não usavam nenhum medicamento. Conclusão: A população do sexo feminino aguardando artroplastia total de joelho deve ser considerada em risco de acometimento pela osteoporose, confirmando dados recentes da literatura. Nível de Evidência III, Estudo de Caso Controle.

Descritores: Osteoporose. Climatério. Artroplastia.

Citation: Sadigursky D, Barreto Junior LA, Lobão DM, Carneiro RJ, Colavolpe PO. Osteoporosis in brazilian patients awaiting knee arthroplasty. Acta Ortop Bras. [online]. 2017;25(3):74-7. Available from URL: http://www.scielo.br/aob.

\section{INTRODUCTION}

IBGE data from 1994 can be used to estimate that in Brazil there are 2.5 million osteoporotic individuals and 105,000 cases of hip fractures per year, resulting in a cost of approximately 630 million reais. ${ }^{1}$ In a population-based study, Pinheiro et al. ${ }^{2}$ demonstrated that smoking was the most important risk factor for osteoporosis in men. For women, the main factors are advanced age, early menopause, higher phosphorus intake, chronic use of benzodiazepines and family history of hip fracture after age 50 (first-degree relatives). Sedentary lifestyle, worsened quality of life and diabetes mellitus (DM) were considered common risk factors in both sexes. A prevalence study reported that higher body mass index (BMI) was associated with lower risk of disease involvement. ${ }^{1}$

Total knee arthroplasty (TKA) is a highly successful operation for treating degenerative changes of the knee such as osteoarthritis and demand for this procedure is growing worldwide due to aging populations and the need to preserve their quality of life. ${ }^{3,4}$ According to the National Institutes of Health Consensus, the most common long-term complications are aseptic loosening, pain and functional limitation, progressive bone loss, polyethylene wear and infection. ${ }^{4}$ Aseptic loosening leads to nearly half of indications for revision of primary arthroplasties. ${ }^{5}$ The cause of this complication is still the focus of much study and the current explanation is

All authors declare no potential conflict of interest related to this article.

Study conducted at Clínica Ortopédica Traumatológica, Centro de Estudos em Ortopedia e Traumatologia, Salvador, BA, Brazil.

Correspondence: R. Colmar Americano da Costa, 121, Pituba, Salvador, BA, Brazil.41830-600. davidsad@gmail.com

Article received in 07/31/2016, approved in 11/08/2016. 
multifactorial, involving adaptive bone remodeling (stress shielding), micro-movement, high intra-articular pressure and individual susceptibility to microparticles. ${ }^{6}$ Furthermore, osteolysis is a factor that contributes to loosening of the implant and in some cases is related to osteoporosis. ${ }^{7}$

Some authors speculate that patients with osteoporosis have increased risk for periprosthetic fractures and consequently loosening of the implant due to the presence of micro-fractures and loss of contiguity in the bone tissue in this group. ${ }^{4,8}$

Domingues et al. ${ }^{9}$ found a $20.7 \%$ prevalence of osteoporosis and $37.9 \%$ for osteopenia in patients awaiting total hip arthroplasty. Additionally, the same study found a high prevalence of inadequate serum vitamin D levels, with only $16.6 \%$ of patients demonstrating levels considered normal (>30 ng/ml).

Based on the data above from the current literature, the present study aims to determine the prevalence of osteoporosis in patients undergoing TKA and also compares calcium and vitamin D levels, as well as preoperative densitometry findings. It is extremely important to understand the impact of this disease on women's health, since there are currently no studies in the literature correlating osteoporosis and TKA.

The objectives of the study were to determine the prevalence of osteoporosis prior to TKA in female patients and correlate levels of pain and functional capacity in patients with decreased bone mass in order to assess whether patients with osteoporosis and osteopenia demonstrate clinical profiles comparable to the population with normal bone density levels. The study also aimed to demonstrate if the involvement of osteoporosis had some direct or inverse correlation with the degree of functional limitation and pain prior to surgery.

\section{METHODS}

This original study is cross-sectional, descriptive and observational. We assessed 60 patients over 55 years of age prior to TKA; only female patients were selected. Data were collected from july 2015 to february 2016.

This study was approved by the institutional review board under CAAE number 49258815.9.0000.5032. The subjects involved in this study signed a free and informed consent form.

Inclusion criteria were: diagnosis of osteoarthritis of the knee confirmed by radiography, scheduled TKA procedure and consent to participate in the study.

Exclusion criteria were: previous infection, congenital diseases, neoplasms, inflammatory arthritis, secondary osteoporosis, previous orthopedic surgery, hypothyroidism, decompensated DM and use of corticosteroids.

Bone mineral density (BMD) was measured by dual-energy $x$-ray absorptiometry (DEXA) in the femur and hip of all patients. Only the lower bone mass values were recorded in each component of the sample.

Osteoporosis was defined as a decrease in bone mass of at least 2.5 standard deviations from the mean young adult BMD (T-score $<-2.5$ ) and osteopenia was defined in patients with BMD values between -1 and -2.5 standard deviations from the mean peak value in young adults. ${ }^{2}$

A comparison of pain and functional impairment was established between patients with and without osteoporosis to establish correlations between the degree of osteoarthritis and decreased bone mass. Three questionnaires were used: the Western Ontario and McMaster Universities Osteoarthritis index (WOMAC), ${ }^{10}$ the Knee Society Score index (KSS), ${ }^{11}$ and the Visual Analog Pain Scale (VAS). ${ }^{12}$ The questionnaires were applied to all patients preoperatively. The Ahlback classification modified by Keyes et al. apud Galli et al. ${ }^{13}$ was used to establish the degree to which the knee joint is compromised in knee osteoarthritis. We also compared fracture involvement in the groups with osteoporosis, osteopenia and no changes in BMD in order to identify patterns that worsen quality of life in these patients.

The angular deviation of the lower limbs (LL) was assessed in all patients via physical examination and panoramic radiography. $X$-rays of all patients were taken from the front and profile views, as well as an axial view of the patella at $45^{\circ}$ knee flexion, in addition to front and profile panoramic radiography; patients were classified as genu varum or genu valgum.

The variables analyzed were age, sex, degree of deformity, comorbidities, lifestyle habits (particularly smoking and alcoholism), serum level of $25-\mathrm{OH}-\mathrm{D}$, ionic calcium, presence of osteoporosis and osteopenia according to BMD, use of medications to treat osteoporosis/osteopenia, hormone replacement therapy, vitamin D or calcium supplementation, BMI and previous fractures.

The statistical analysis was conducted using Excel 2003 (Microsoft Corporation, Redmond, WA, USA) and SPSS 20.0 (IBM, New York, NY, USA) software. The tests were performed at a $5 \%$ significance level. The qualitative characteristics were described using absolute and relative frequencies and the quantitative measures were described in summary measures (mean, standard deviation, minimum and maximum). The quantitative characteristics were described according to the presence of osteoporosis and compared between patients with and without osteoporosis using Mann-Whitney tests.

\section{RESULTS}

Table 1 describes the sample studied. The average age was 71.4 years with standard deviation (SD) of 6.9 , minimum of 58 years and maximum of 85 .

Mean ionic calcium was 4.85 with SD of 0.31 ; mean vitamin D (25-OH-cholecalciferol) was 32 with SD of 7.12. Four patients were smokers and five used alcohol. Table 1 shows the comorbidities found in each patient through the pre-procedure diagnostic questionnaire, medical records and physical examination. Hypertension was most frequent (35\%), followed by DM (18.3\%), hypothyroidism (10\%) and dyslipidemia (10\%). No other clinically relevant comorbidities were reported by the patients.

Table 2 below shows the presence of alterations in BMD. Osteoporosis was present in 10 of the individuals surveyed (16.7\%) and osteopenia in 9 (15\%).

Angular deviation in the lower limbs (genus valgum, genus varum) was compared in patients with osteopenia, osteoporosis, or without BMD changes. Genus valgum was detected in $70 \%$ of patients with osteoporosis and $55.6 \%$ of patients with osteopenia. Genus varum was the most common change $(61 \%)$ in patients without changes in the BMD.

We also evaluated the BMI of patients in each group based on changes in BMD (osteoporosis, osteopenia and no bone changes). The group classified as having osteoporosis had a mean BMI of 27.3 (SD 2.9), the osteopenia group had mean BMl of 27.44 (SD 3.6) and the group with no changes in the densitometry had a mean BMl of 27.15 (SD 3.0).

Table 3 contrasts the bone density classification and fracture history of the patients. We can see that the group with osteoporosis had the most fractures, most frequently femur fracture (20\%).

Table 4 shows the use of biphosphonates for prevention and/or treatment and also divides patients by osteoporosis, osteopenia and no bone alterations. Most of the osteopenia group did not use any anti-resorption medication (55.6\%), while most of the patients with osteoporosis used alendronate or no medication (30\%). Table 5 describes pain levels according to $\mathrm{VAS}^{12}$ and functional capacity according to $\mathrm{KSS}^{14}$ and WOMAC ${ }^{10}$ in patients with 
osteoporosis, osteopenia and no bone changes. Note that there was no statistically significant difference for any scale in the preoperative period and that $100 \%$ of the evaluated patients with osteoporosis showed insufficient levels of $25-\mathrm{OH}$-cholecalciferol (reference value: $<30 \mathrm{ng} / \mathrm{mL}$ ).

Table 1. Description of the sample.

\begin{tabular}{|c|c|c|}
\hline Variable & $\mathrm{N}=60(\%)$ & Mean SD (min-max) \\
\hline Age (years) & & $71.4 \pm 6.9(58-85)$ \\
\hline Ionic calcium & & $4.85 \pm 0.31(4.2-5.5)$ \\
\hline Vitamin D (25-OH-cholecalciferol) & & $32 \pm 7.12(22-43)$ \\
\hline \multicolumn{3}{|l|}{ Lifestyle factors } \\
\hline Tobacco user & $4(6.7)$ & \\
\hline Alcohol user & $5(8.3)$ & \\
\hline Non-user of tobacco or alcohol & $51(85)$ & \\
\hline \multicolumn{3}{|l|}{ Comorbidities } \\
\hline High blood pressure & $21(35)$ & \\
\hline Hypothyroidism & $6(10)$ & \\
\hline Diabetes mellitus & $11(18.3)$ & \\
\hline Dyslipidemia & $6(10)$ & \\
\hline Heart failure & $1(1.7)$ & \\
\hline History of breast cancer & $1(1.7)$ & \\
\hline No comorbidities & $26(43.33)$ & \\
\hline
\end{tabular}

Table 2. Changes in bone density in the sample.

\begin{tabular}{c|c}
\hline Changes in bone density & $\mathbf{N}(\%)$ \\
\hline Osteoporosis & $10(16.7)$ \\
\hline Osteopenia & $9(15)$ \\
\hline Normal & $41(68.3)$ \\
\hline
\end{tabular}

Table 3. History of fractures in each group.

\begin{tabular}{|c|c|c|c|c|}
\hline \multirow[b]{2}{*}{ Fracture } & \multicolumn{3}{|c|}{$\begin{array}{l}\text { Group of patients according to changes } \\
\text { in bone densitometry (mean SD) }\end{array}$} & \multirow{2}{*}{$\begin{array}{c}p^{*} \\
(95 \% \mathrm{Cl})\end{array}$} \\
\hline & $\begin{array}{l}\text { Osteoporosis } \\
n=10\end{array}$ & $\begin{array}{l}\text { Osteopenia } \\
n=9\end{array}$ & $\begin{array}{c}\text { No bone } \\
\text { changes } \\
n=41\end{array}$ & \\
\hline $\begin{array}{c}\text { Spinal fractures } \\
\text { (due to } \\
\text { osteoporosis) }\end{array}$ & $1(10)$ & $1(11.1)$ & 0 & \multirow{4}{*}{$\begin{array}{c}0.803 \\
(0.796- \\
0.811)\end{array}$} \\
\hline $\begin{array}{l}\text { Fracture of } \\
\text { proximal femur }\end{array}$ & $2(20)$ & 0 & $1(2.4)$ & \\
\hline $\begin{array}{l}\text { Fracture of } \\
\text { distal radius }\end{array}$ & $1(10)$ & 0 & 0 & \\
\hline No fractures & $6(60)$ & $8(88.9)$ & 40 (97.6) & \\
\hline
\end{tabular}

Table 4. Medications used in each group

\begin{tabular}{c|c|c|c}
\hline \multirow{2}{*}{ Variable } & \multicolumn{3}{|c}{$\begin{array}{c}\text { Group of patients according to } \\
\text { changes in bone densitometry (\%) }\end{array}$} \\
\cline { 2 - 4 } & $\begin{array}{c}\text { Osteoporosis } \\
\mathbf{n}=10\end{array}$ & $\begin{array}{c}\text { Osteopenia } \\
\mathbf{n}=9\end{array}$ & $\begin{array}{c}\text { Normal BMD } \\
\mathbf{n}=41\end{array}$ \\
\hline Medication for osteoporosis & & & $41(100)$ \\
\hline None & $3(30)$ & $5(55.6)$ & 0 \\
\hline Risedronate & $2(20)$ & $2(22.2)$ & 0 \\
\hline Alendronate & $3(30)$ & $1(11.1)$ & 0 \\
\hline Ibandronate & 0 & $1(11.1)$ & 0 \\
\hline Zoledronic acid & $2(20)$ & 0 & 0 \\
\hline Denosumab & 0 & 0 & 0 \\
\hline Teriparatide & 0 & 0 & 0 \\
\hline Hormone replacement & 0 & $3(33.3)$ & $6(66.7)$ \\
\hline Vitamin D replacement & $7(70)$ & & \\
\hline
\end{tabular}

Table 5. Comparative analysis of patients with osteoporosis, osteopenia and normal patients according to VAS, KSS and WOMAC scores*

\begin{tabular}{|c|c|c|}
\hline \multicolumn{2}{|c|}{$\begin{array}{c}\text { Group of patients according to changes } \\
\text { in bone densitometry (mean SD) }\end{array}$} & \multirow{2}{*}{$P^{\star}(95 \% \mathrm{Cl})$} \\
\hline $\begin{array}{c}\text { Osteoporosis } \\
\mathrm{n}=10\end{array}$ & $\begin{array}{c}\text { Osteopenia } \\
\mathrm{n}=9\end{array}$ & $\begin{array}{c}\text { No bone } \\
\text { changes } \\
\mathrm{n}=41\end{array}$
\end{tabular}

Visual Analog Scale

\begin{tabular}{c|c|c|c|c}
\hline Preoperative & $8.2 \pm 0.79$ & $7.8 \pm 0.9$ & $7.8 \pm 0.6$ & $0.346(0.337-0.355)$ \\
\hline \multicolumn{5}{c}{ Knee society score } \\
\hline Preoperative & $44.1 \pm 5.67$ & $39.8 \pm 5.3$ & $42.6 \pm 6.5$ & $0.273(0.265 / 0.282)$ \\
\hline \multicolumn{5}{c}{ WOMAC score } \\
\hline Preoperative & $60.4 \pm 7.15$ & $59.7 \pm 7.0$ & $62.2 \pm 7.7$ & $0.356(0.346 / 0.365)$ \\
\hline
\end{tabular}

*VAS = Visual Analog Pain Scale, Knee Society Score, Western Ontario and McMaster Universities osteoarthritis index. ${ }^{*}$ Kruskal-Wallis test with statistical significance if $p$ is less than 0.05 .

\section{DISCUSSION}

This is the first prevalence study that establishes a correlation between osteoporosis and TKA. Patients with osteoarthritis who need joint replacement are predominantly elderly women, a population with a high risk of developing osteoporosis,,$^{15}$ which justifies the selection of only women for this study. The selected age range coincides with menopause.

In this study we found that $31.7 \%$ of patients had decreases in bone mass and $16.7 \%$ had a confirmed diagnosis of osteoporosis from BMD and $15 \%$ had osteopenia. This value can be considered low in comparison with the study conducted by Pinheiro et al..$^{2}$ on a sample of 4,332 patients in the metropolitan region of São Paulo, in which $33 \%$ of postmenopausal women showed osteoporosis of the lumbar spine or femur. Faisal-Cury and Zacchello found a 32.7\% prevalence of osteoporosis in a group of 999 women above 49 years of age. We can therefore speculate that the difference between the results obtained may derive from differences in sample size. Bisphosphonates are analogous to pyrophosphates and have an anti-resorptive action; they are among the most common therapeutic options for treating osteoporosis ${ }^{16}$ in order to prevent the occurrence 
of fractures. We found that $30 \%$ of patients with osteoporosis and $55.6 \%$ of patients with osteopenia were not taking bisphosphonate medication prior to the assessment. There was no statistically significant difference between the BMI of patients with osteoporosis, osteopenia and those with no changes in bone mass. The scores for the VAS, ${ }^{12} \mathrm{KSS}^{11}$ and WOMAC ${ }^{10}$ did not demonstrate a statistically significant difference between patients with and without osteoporosis. Smoking has been established in the literature as a risk factor for osteoporosis. Only $6.7 \%$ of the population studied were smokers, but $80 \%$ of the patients who smoked had osteoporosis. ${ }^{17}$

Hormone replacement therapy is recommended for postmenopausal patients as the best way of preventing osteoporotic fractures, especially in the first years after last menstruation, although it should be used cautiously because of the increased risk of embolism and breast cancer. ${ }^{15}$ Based on this information, this study found that $33.3 \%$ of patients with osteopenia and no patients with unaltered bone mineral densitometry results used hormone replacement therapy. This finding may show insufficient monitoring for this disease in this group of women.

Calcitriol (1.25-dihidroxicolecalciferol) is the active form of vitamin $\mathrm{D}$ and plays a prominent role in bone metabolism, contributing to intestinal absorption of calcium and inhibiting resorption of the bone matrix. ${ }^{18}$ According to Glowacki et al. ${ }^{19}$ one of the most important factors contributing to its activation is exposure to sunlight. Serum values between $20-29 \mathrm{ng} / \mathrm{mL}$ indicate insufficient vitamin D, while levels below $20 \mathrm{ng} / \mathrm{mL}$ indicate an established deficiency of the hormone. ${ }^{20} \mathrm{~A}$ significant difference was seen in vitamin D levels among the groups with osteoporosis or osteopenia and no changes in bone mass. All patients diagnosed with osteoporosis showed insufficient levels, which indicates the significant influence this hormone deficiency plays in the presentation of the disease.

One limitation of this study was the inclusion of the entire sample which fit the inclusion criteria, creating a convenience sample. A second limitation was the lack of a control group with patients without osteoarthritis matched for age and sex. The BMD only evaluated the hip and lumbar spine because these regions are most commonly included in assessment of the disease. Because this was a prevalence study, it was not possible to establish a causal relationship between exposure factors and outcomes.

The female population scheduled for TKA should receive special attention during the preoperative period since this group is notably susceptible to osteoporosis, in order to prevent complications such as osteoporotic and periprosthetic fractures and infection, which may lead to early loosening of the implant. We can infer that osteoarthritis does not appear to protect against osteoporosis, according to the same findings demonstrated by Domingues et al. ${ }^{9}$ if special attention is given to diagnosis in this group of patients and appropriate treatment is established

\section{CONCLUSION}

The prevalence of osteoporosis in the group studied was $16.7 \%$, while the prevalence of osteopenia was $15 \%$. The female population waiting for TKA should be considered at risk for involvement of osteoporosis in the studied population. The data we found resemble those found in the international literature.

No statistically significant difference was observed between pain levels and functional capacity among groups with osteoporosis, osteopenia, or with normal levels of bone mineral density.

AUTHORS' CONTRIBUTIONS: Each author contributed individually and significantly to the development of the manuscript. DS (0000-0003-3437-6180)* and LABJ (0000-0001-5368-0802)* were the main contributors in writing the text. POC (0000-0002-6697-7469)*, RJFC (0000-0001-5450-064X)*, and DS collected the data, monitored the patients, and assembled the database. DMVL (0000-0003-0378-3664)* and DS evaluated the data from the statistical analysis. DS, LABJ and DMVL performed the bibliographic research, reviewed the manuscript, and contributed to the study's intellectual concept. *ORCID (Open Researcher and Contributor ID).

\section{REFERENCES}

1. Faisal-Cury A, Zacchello KP. Osteoporose: prevalência e fatores de risco em mulheres de clínica privada maiores de 49 anos de idade. Acta Ortop Bras. 2007;15(3):146-50

2. Pinheiro MM, Ciconelli RM, Jacques N O, Genaro PS, Martini LA, Ferraz MB. The burden of osteoporosis in Brazil: regional data from fractures in adult men and women - The Brazilian Osteoporosis Study (BRAZOS). Rev Bras Reumatol. 2010;50(2):113-20.

3. Zeni JA Jr, Axe MJ, Snyder-Mackler L. Clinical predictors of elective total joint replacement in persons with end-stage knee osteoarthritis. BMC Musculoskelet Disord. 2010;11:86.

4. Carvalho Júnior LH, Castro CAC, Gonçalves MBJ, Rodrigues LCM, Lopes FL, et al. Complicações de curto prazo da artroplastia total do joelho: avaliação de 120 casos. Rev Bras Ortop. 2006;41(5):162-6.

5. Letaif OB, Frucchi R, D'Elia CO, Demange MK, Albuquerque RFM, Rezende $\mathrm{MU}$, et al. Functional comparison between septic and aseptic knee arthroplasty review. Acta Ortop Bras. 2009;17(3):159-61.

6. Jasper LL, Jones CA, Mollins J, Pohar SL, Beaupre LA. Risk factors for revision of total knee arthroplasty: a scoping review. BMC Musculoskelet Disord. 2016;17:182.

7. Fraser JF, Werner S, Jacofsky DJ. Wear and loosening in total knee arthroplasty: a quick review. J Knee Surg. 2015;28(2):139-44.

8. Abu-Amer Y, Darwech I, Clohisy JC. Aseptic loosening of total joint replacements: mechanisms underlying osteolysis and potential therapies. Arthritis Res Ther. 2007;9 Suppl 1:S6

9. Domingues VR, de Campos GC, Plapler PG, de Rezende MU. Prevalence of osteoporosis in patients awaiting total hip arthroplasty. Acta Ortop Bras. 2015;23(1):34-7.

10. Baron G, Tubach F, Ravaud P, Logeart I, Dougados M. Validation of a short form of the Western Ontario and McMaster Universities Osteoarthritis Index function subscale in hip and knee osteoarthritis. Arthritis Care Res. 2007:57(4):633-8.

11. Silva ALP, Demange MK, Gobbi RG, Silva TFC, Pécora JR, Croci AT. Translation and validation of the Knee Society Score - KSS for Brazilian Portuguese. Acta Ortop Bras. 2012;20(1):25-30.

12. Martinez JE, Grassi DC, Marques LG. Análise da aplicabilidade de três instrumentos de avaliação de dor em distintas unidades de atendimento: ambulatório enfermaria e urgência. Rev Bras Reumatol. 2011;51(4):299-308.

13. Galli M, De Santis V, Tafuro L. Reliability of the Ahlbäck classification of knee osteoarthritis. Osteoarthritis Cartilage. 2003;11(8):580-4.

14. Silva ALP, Demange MK, Gobbi RG, da Silva TFC, Pécora JR, Croci AT. Translation and Validation of the Knee Society Score - KSS for Brazilian Portuguese. Acta Ortop Bras. 2012;20(1):25-30.

15. Radominski SC, Pinto-Neto AM, Marinho RM, Costa-Paiva LHS, Pereira FA Urbanetz AA, et al. Osteoporose em mulheres na pós-menopausa. Rev Bras Reumatol. 2004;44(6):426-34.

16. Leite MOR. Tratamento da osteoporose pós-menopansa. Arq Bras Endocrinol Amp Metabol. 1999;43(6):442-5.

17. Holm JP, Hyldstrup L, Jensen JB. Time trends in osteoporosis risk factor profiles: a comparative analysis of risk factors, comorbidities and medications over twelve years. Endocrine. 2016;54(1):241-55.

18. Arden NK, Cro S, Sheard S, Doré CJ, Bara A, Tebbs SA, et al. The effect of vitamin D supplementation on knee osteoarthritis, the VIDEO study: a randomised controlled trial. Osteoarthritis Cartilage. 2016;24(11):1858-1866.

19. Glowacki J, Hurwitz S, Thornhill TS, Kelly M, LeBoff MS. Osteoporosis and vitamin-D deficiency among postmenopausal women with osteoarthritis undergoing total hip arthroplasty. J Bone Joint Surg Am. 2003;85-A(12):2371-7.

20. Ghosh B, Pal T, Ganguly S, Ghosh A. A study of the prevalence of osteoporosis and hypovitaminosis $D$ in patients with primary knee osteoarthritis. J Clin Orthop Trauma. 2014;5(4):199-202. 